\title{
Microbiological pollutants in air and antibiotic resistance profile of some bacterial isolates
}

\author{
Md. Shahinur Kabir*, Farzana Mridha, Salma Islam and Md. Shorifujjaman \\ Department of Botany, Jahangirnagar University, Savar, Dhaka 1342, Bangladesh
}

\begin{abstract}
Microbiological quality assessment is one of the most important investigations to determine the pollution of indoor and outdoor air. To evaluate the microbial load in air, samples were collected from 3 different outdoor and 3 different indoor sites within Jahangirnagar University campus. In outdoor air, bacterial and fungal counts varied from $117-7284 \mathrm{CFU} / \mathrm{m}^{3}$ and 88 $5287 \mathrm{CFU} / \mathrm{m}^{3}$, respectively. On the other hand, in indoor air bacterial and fungal counts varied from $440-6226 \mathrm{CFU} / \mathrm{m}^{3}$ and $88-5874 \mathrm{CFU} / \mathrm{m}^{3}$, respectively. Furthermore, to reveal the antibiotic resistance profile, Staphylococcus aureus isolates were subjected to antibiogram study against 14 antibiotics. Among the isolates, $87.5 \%$ exhibited resistance to ceftazidime; $50 \%$ to penicillin $\mathrm{G} ; 31.25 \%$ to cefotaxime; $25 \%$ to ceftriaxone, cefuroxime, cloxacillin; and $18.75 \%$ to amoxicillin. None of the isolates showed resistance to amikacin, ciprofloxacin, erythromycin, gentamicin, imipenem, nitrofurantoin and vancomycin. The presence of antibiotic-resistant bacteria in air may cause serious health hazard to the people living in this area.
\end{abstract}

Key words: Air pollution, bacteria, fungi, antibiotic resistance.

\section{INTRODUCTION}

Human being, on an average, inhales $14 \mathrm{~m}^{3}$ air per day (Brochu et al., 2006). Presence of high concentration of microorganisms in the inhaled air thus can adversely affect health and activities of the people. Pathogenic living cells present in the air or the chemical substances secreted by the airborne microbes can cause severe human infections and diseases (Stryjakowska-Sekulska et al., 2007). Information on microbial concentration in the indoor and outdoor air is necessary not only to estimate the health hazard associated with the inhaled air but also to formulate the strategy to minimize microbial air pollution.

Microbiological contamination of air is mostly caused by bacteria and fungi. They can exist in air as an individual entity or create aggregates of biological structures. However, the survival of microbial cells in air depends on their ability to resist different types of stress viz., ultraviolet radiation, desiccation, starvation etc. Some microbial cells produce pigments or mucous halo to protect them form harmful effect of ultraviolet radiation. Spore formation is one of most widely used strategies adopted by many microbes to survive in unfavorable conditions and dissemination of offspring. Airborne microscopic contaminants of biological origin, known as bioaerosol, are easily translocated by winds and air currents from one ecosystem to another, making them an important vehicle for the

\footnotetext{
* Corresponding author. E-mail: shahin@juniv.edu
} 
spread of hazardous microorganisms (Eduard et al., 2012). Bioaerosols occur as droplets or solid particles and derive from a multitude of natural and artificial sources, such as surface waters, dry soils and agricultural activities (Brandal et al., 2014).

Jahangirnagar university $\left(23^{\circ} 52^{\prime} 44.62^{\prime \prime} \mathrm{N}\right.$ latitude and $90^{\circ} 16^{\prime} 8.57^{\prime \prime E}$ longitude), situated about $32 \mathrm{~km}$ north-west from the capital city Dhaka, spread over an area of 697.56 acres and about 16 meter high from the mean sea level. There are many woodland, grassland and small lakes in the campus which is a habitat for wildlife and migratory birds. The Jahangirnagar University (JU) campus is surrounded by livestock farms, training centers, agricultural fields and Dhaka-Aricha highway. Due to the presence of large number of herbs, shrubs and trees, the JU campus is generally considered as sanitarium. However, systematic study on the microbiological quality of indoor and outdoor air of this University and the antibiotic resistance profile of the airborne bacteria is almost absent. Thus, this study was undertaken to reveal the actual picture of the air quality of JU campus.

\section{MATERIALS AND METHODS}

Sampling strategy: Air samples were collected from 3 different indoor (ID1: Old Arts Building, ID2: Central Library, and ID3: Faculty of Biological Sciences Building) and 3 different outdoor sites (OD1: Bishmile Area, OD2: Outside of Al-Beruni Hall, and OD3: Central Playground) of JU campus (Fig. 1).

Collection of samples: The settle plate method was used to collect airborne culturable microbes (Hayleeyesus and Manaye, 2014). Petri plates containing nutrient agar and potato dextrose agar were used to collect bacteria and fungi, respectively. The plates were exposed to air about $1 \mathrm{~m}$ above the land or floor for about 30 minutes in the day time.

Enumeration of microbes: The exposed plates after the required time were covered with the lid and incubated at $37{ }^{\circ} \mathrm{C}$ for $24-48 \mathrm{~h}$ for the growth of bacteria and at around $25{ }^{\circ} \mathrm{C}$ for at least 5 days for the growth of fungi, respectively. The resultant colonies were counted and converted into colony forming unit per cubic meter of air $\left(\mathrm{CFU} / \mathrm{m}^{3}\right)$ using Omeliansky formula (Hayleeyesus and Manaye, 2014):

$\mathrm{N}=5 \mathrm{a} \times 10^{4}(\mathrm{bt})^{-1}$

Where:

$\mathrm{N}=\mathrm{CFU} / \mathrm{m}^{3}$ of air

$\mathrm{a}=$ number of colonies per Petri dish

$\mathrm{b}=$ dish surface $\left(\mathrm{cm}^{2}\right)$

$\mathrm{t}=$ exposure time $(\mathrm{min})$

Isolation and identification of Staphylococcus aureus: For isolation of S. aureus, colonies grew on nutrient agar plates were streaked onto mannitol salt agar (MSA). The plates were incubated at $37{ }^{\circ} \mathrm{C}$ for $24 \mathrm{~h}$ for the growth of bacteria. The appearance of golden yellow colony with a yellow zone surrounding the colony was considered to be 
presumptive $S$. aureus. The suspected colonies of $S$. aureus were identified by morphological and standard biochemical tests (Brooks et al., 2007; Cappuccino and Sherman 1996; Holt et al., 1994). Based on the test results, 16 isolates were finally identified as $S$. aureus.

Antibiotic susceptibility test: Susceptibility of the isolated $S$. aureus to antibiotics was determined in vitro by employing disc diffusion method (Bauer et al., 1966) and recommendations of Clinical and Laboratory Standard Institute (CLSI, 2006). Available antibiotic disc (Oxoid, UK) of amoxicillin $(10 \mu \mathrm{g})$, amikacin $(30 \mu \mathrm{g})$, cefotaxime $(30 \mu \mathrm{g})$, ceftazidime $(30 \mu \mathrm{g})$, ceftriaxone $(30 \mu \mathrm{g})$, cefuroxime $(30 \mu \mathrm{g})$, ciprofloxacin $(5 \mu \mathrm{g})$, cloxacillin $(5 \mu \mathrm{g})$, erythromycin $(15 \mu \mathrm{g})$, gentamicin $(10 \mu \mathrm{g})$, imipenem $(10 \mu \mathrm{g})$, nitrofurantoin $(300 \mu \mathrm{g})$, penicillin $\mathrm{G}(10 \mathrm{units})$ and vancomycin $(30 \mu \mathrm{g})$ were used for the test. A portion of $S$. aureus colony grown on nutrient agar medium was inoculated in nutrient broth and incubated at $37{ }^{\circ} \mathrm{C}$ to obtain a young culture.

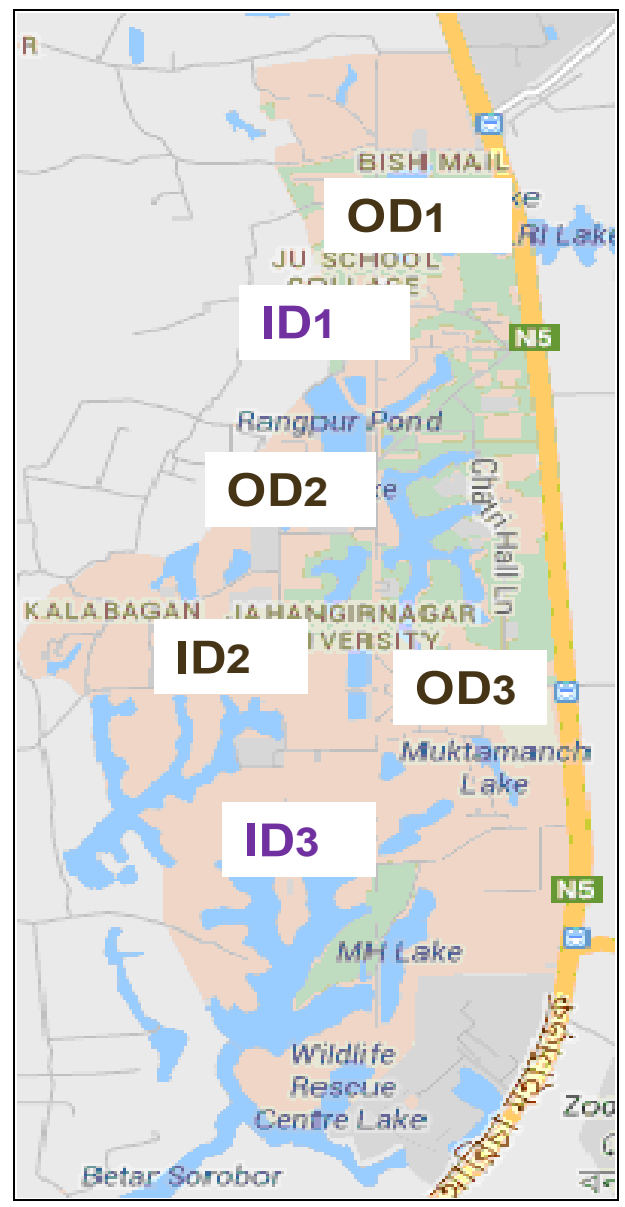

Fig. 1. Map showing outdoor (OD) and indoor (ID) sample collection sites 
A cotton swab was dipped in the suspension and the excess fluid was removed by pushing and rotating the cotton swab inside the wall of the tube just above the fluid level. Then the swab was streaked over the surface of Mueller-Hinton agar to obtain uniform inoculums. Antibiotic impregnated discs were then aseptically placed on the surface of the MuellerHinton agar medium with the help of sterile forceps. Each disc was gently pressed down onto the medium to ensure complete contact with agar surface. The plates were inverted and incubated at $37{ }^{\circ} \mathrm{C}$. After $18 \mathrm{~h}$ incubation, the plates were examined and the diameter of the zones of inhibition was measured to the nearest whole millimeter. The $S$. aureus isolates were classified as sensitive and resistant to a particular antibiotic based on the diameter of zone of inhibition.

\section{RESULTS AND DISCUSSION}

In outdoor air, bacterial count varied from $3965-7284 \mathrm{CFU} / \mathrm{m}^{3}, 646-4112 \mathrm{CFU} / \mathrm{m}^{3}, 117$ - $2408 \mathrm{CFU} / \mathrm{m}^{3}$ in March, April and May 2014, respectively. Whereas, fungal count in outdoor air varied from $2056-5287 \mathrm{CFU} / \mathrm{m}^{3}, 88-4141 \mathrm{CFU} / \mathrm{m}^{3}, 822-1821 \mathrm{CFU} / \mathrm{m}^{3}$ in March, April and May 2014, respectively (Table 1). Bacterial count in indoor environments varied from $2643-6226 \mathrm{CFU} / \mathrm{m}^{3}, 1087-1586 \mathrm{CFU} / \mathrm{m}^{3}, 440-1380$ $\mathrm{CFU} / \mathrm{m}^{3}$ in March, April and May 2014, respectively. Whereas, in indoor air fungal count varied from $881-4024 \mathrm{CFU} / \mathrm{m}^{3}, 88-646 \mathrm{CFU} / \mathrm{m}^{3}, 617-5874 \mathrm{CFU} / \mathrm{m}^{3}$ in March, April and May 2014, respectively (Table 2). The daily activities of people, wastes generated from laboratories and medical centre, wastes from temporary restaurants, movement of transport vehicles and droppings from wildlife are thought to be the principal factors contributing to the buildup and spread of airborne microbial flora in Jahangirnagar University campus. High level of microbial pollution of air was also reported in different countries of the world (Azimi et al., 2013; Ekhaise and Ogboghodo, 2011; Hayleeyesus and Manaye, 2014; Stryjakowska-Sekulska et al., 2007). In this study, among the bacterial genera, Bacillus, Micrococcus and Staphylococcus were most abundant and among the fungal genera, Aspergillus and Penicillium were most abundant. Brandal et al. (2014) reported that Bacillus and Staphylococcus are the most frequent in airborne microflora whereas Bonetta et al. (2010) found Staphylococcus and Micrococcus as the most common bacterial genera in indoor air.

The Commission of the European Communities in 1993 formulated air quality standards for non-industrial premises (CEC, 1993). According to that standard, degree of pollution was classified into 5 categories: very low (bacteria $<50 \mathrm{CFU} / \mathrm{m}^{3}$, fungi $<25 \mathrm{CFU} / \mathrm{m}^{3}$ of air); low (bacteria $50-100 \mathrm{CFU} / \mathrm{m}^{3}$, fungi $25-100 \mathrm{CFU} / \mathrm{m}^{3}$ of air); intermediate (bacteria $100-500 \mathrm{CFU} / \mathrm{m}^{3}$, fungi $100-500 \mathrm{CFU} / \mathrm{m}^{3}$ of air); high (bacteria $500-2000 \mathrm{CFU} / \mathrm{m}^{3}$, fungi $500-2000 \mathrm{CFU} / \mathrm{m}^{3}$ of air); and very high (bacteria $>2000 \mathrm{CFU} / \mathrm{m}^{3}$, fungi $>2000 \mathrm{CFU} / \mathrm{m}^{3}$ of air). Although this standard was recommended for indoor air, we used the same for both indoor and outdoor air to get an overall picture of the pollution status in JU campus. 
Table 1. Microbiological quality of outdoor air during the study period

\begin{tabular}{|c|c|c|c|c|}
\hline $\begin{array}{l}\text { Month } \\
\text { (in 2014) }\end{array}$ & Sampling site & Replication & $\begin{array}{c}\text { Bacterial count } \\
\left(\mathrm{CFU} / \mathrm{m}^{3}\right)\end{array}$ & $\begin{array}{c}\text { Fungal count } \\
\left(\mathrm{CFU} / \mathrm{m}^{3}\right)\end{array}$ \\
\hline \multirow[t]{9}{*}{ March } & OD1 & 1 & 5343 & 3935 \\
\hline & & 2 & 5874 & 5287 \\
\hline & & 3 & 7284 & 2643 \\
\hline & OD2 & 1 & 3965 & 2203 \\
\hline & & 2 & 5110 & 2320 \\
\hline & & 3 & 6315 & 2261 \\
\hline & OD3 & 1 & 4993 & 2056 \\
\hline & & 2 & 6285 & 2790 \\
\hline & & 3 & 5727 & 2996 \\
\hline \multirow[t]{9}{*}{ April } & OD1 & 1 & 646 & 2408 \\
\hline & & 2 & 4024 & 2373 \\
\hline & & 3 & 4112 & 4141 \\
\hline & OD2 & 1 & 852 & 411 \\
\hline & & 2 & 1057 & 88 \\
\hline & & 3 & 1410 & 499 \\
\hline & OD3 & 1 & 1087 & 264 \\
\hline & & 2 & 1322 & 441 \\
\hline & & 3 & 1175 & 352 \\
\hline \multirow[t]{9}{*}{ May } & OD1 & 1 & 117 & 1674 \\
\hline & & 2 & 822 & 1234 \\
\hline & & 3 & 793 & 1439 \\
\hline & OD2 & 1 & 1468 & 1821 \\
\hline & & 2 & 264 & 1116 \\
\hline & & 3 & 1380 & 822 \\
\hline & OD3 & 1 & 2408 & 940 \\
\hline & & 2 & 2174 & 910 \\
\hline & & 3 & 676 & 822 \\
\hline
\end{tabular}

In outdoor air, highest average bacterial count was at OD1 $\left(6167 \mathrm{CFU} / \mathrm{m}^{3}\right)$ in March and lowest at OD1 $\left(577 \mathrm{CFU} / \mathrm{m}^{3}\right)$ in May 2014. The average fungal count was also highest at OD1 (3955 CFU/m $\left.\mathrm{m}^{3}\right)$ in March and lowest at OD1 (333 CFU/m $\left.\mathrm{m}^{3}\right)$ in April 2014 (Table 3). In indoor air, highest average bacterial count was at ID3 $\left(5786 \mathrm{CFU} / \mathrm{m}^{3}\right)$ in March and lowest at ID2 $\left(764 \mathrm{CFU} / \mathrm{m}^{3}\right)$ in May 2014. The average fungal count was highest at ID3 $\left(2731 \mathrm{CFU} / \mathrm{m}^{3}\right)$ in May and lowest at ID3 $\left(303 \mathrm{CFU} / \mathrm{m}^{3}\right)$ in April 2014 (Table 4). Based on the sanitary standards for non-industrial premises (CEC, 1993), very high microbial pollution was observed at all the sampling sites in March 2014 (Table 3 and 4). Air pollution status gradually improved in all the 3 outdoor sampling sites in May 2014 (Table 3). Microbial air pollution status also improved in 2 indoor sampling sites at the same time (Table 4). 
Table 2. Microbiological quality of indoor air during the study period

\begin{tabular}{|c|c|c|c|c|}
\hline $\begin{array}{l}\text { Month } \\
\text { (in 2014) }\end{array}$ & Sampling site & Replication & $\begin{array}{l}\text { Bacterial count } \\
\left(\mathrm{CFU} / \mathrm{m}^{3}\right)\end{array}$ & $\begin{array}{c}\text { Fungal count } \\
\left(\mathrm{CFU} / \mathrm{m}^{3}\right)\end{array}$ \\
\hline \multirow[t]{9}{*}{ March } & ID1 & 1 & 2937 & 2115 \\
\hline & & 2 & 3642 & 2408 \\
\hline & & 3 & 2643 & 2526 \\
\hline & ID2 & 1 & 3906 & 1116 \\
\hline & & 2 & 3378 & 4024 \\
\hline & & 3 & 2790 & 1527 \\
\hline & ID3 & 1 & 6226 & 1586 \\
\hline & & 2 & 5198 & 1469 \\
\hline & & 3 & 5933 & 881 \\
\hline \multirow[t]{9}{*}{ April } & ID1 & 1 & 1087 & 529 \\
\hline & & 2 & 1322 & 264 \\
\hline & & 3 & 1176 & 646 \\
\hline & ID2 & 1 & 1175 & 587 \\
\hline & & 2 & 1351 & 529 \\
\hline & & 3 & 1586 & 617 \\
\hline & ID3 & 1 & 1145 & 352 \\
\hline & & 2 & 1322 & 88 \\
\hline & & 3 & 1410 & 470 \\
\hline \multirow[t]{9}{*}{ May } & ID1 & 1 & 617 & 764 \\
\hline & & 2 & 852 & 617 \\
\hline & & 3 & 1116 & 1527 \\
\hline & ID2 & 1 & 470 & 646 \\
\hline & & 2 & 1380 & 764 \\
\hline & & 3 & 440 & 793 \\
\hline & ID3 & 1 & 587 & 1439 \\
\hline & & 2 & 1145 & 5874 \\
\hline & & 3 & 617 & 881 \\
\hline
\end{tabular}

Table 3. Status of outdoor air quality $(n=3)$

\begin{tabular}{c|c|c|c|c}
\hline $\begin{array}{c}\text { Month } \\
\text { (in 2014) }\end{array}$ & Sampling site & $\begin{array}{c}\text { Bacterial count } \\
\left(\mathrm{CFU} / \mathrm{m}^{3}\right)\end{array}$ & $\begin{array}{c}\text { Fungal count } \\
\left(\mathrm{CFU} / \mathrm{m}^{3}\right)\end{array}$ & Pollution degree* \\
\hline March & OD1 & 6167 & 3955 & Very high \\
& OD2 & 5130 & 2261 & Very high \\
April & OD3 & 5668 & 2614 & Very high \\
& OD1 & 2927 & 2974 & Very high \\
& OD2 & 1106 & 333 & High \\
May & OD3 & 1195 & 352 & High \\
& OD1 & 577 & 1449 & High \\
& OD2 & 1037 & 1253 & High \\
& OD3 & 1753 & 891 & High \\
\hline
\end{tabular}

*Based on sanitary standards for non-industrial premises (CEC, 1993). 
Table 4. Status of indoor air quality $(n=3)$

\begin{tabular}{ccccc}
\hline $\begin{array}{c}\text { Month } \\
\text { (in 2014) })\end{array}$ & Sampling site & $\begin{array}{c}\text { Bacterial count } \\
\left(\mathrm{CFU} / \mathrm{m}^{3}\right)\end{array}$ & $\begin{array}{c}\text { Fungal count } \\
\left(\mathrm{CFU} / \mathrm{m}^{3}\right)\end{array}$ & Pollution degree* \\
\hline March & ID1 & 3074 & 2350 & Very high \\
& ID2 & 3358 & 2222 & Very high \\
\multirow{5}{*}{ April } & ID3 & 5786 & 1312 & Very high \\
& ID1 & 1195 & 480 & High \\
& ID2 & 1371 & 578 & High \\
May & ID3 & 1292 & 303 & High \\
& ID1 & 862 & 969 & High \\
& ID2 & 764 & 734 & High \\
& ID3 & 783 & 2731 & Very High \\
\hline
\end{tabular}

*Based on sanitary standards for non-industrial premises (CEC, 1993).

S. aureus, a Gram-positive bacterium which grows in grape-like cluster, is commonly found in most environments and may survive on dry surfaces for long periods (Reygaert, 2013). Furthermore, this microorganism is naturally equipped with a battery of virulence factors which help it to promote colonization, prevent opsonization, and cytolytic activity. Although, most infections with S. aureus are localized at the area of entry and are selflimiting, presence of many virulence factors gives this microorganism an advantage to cause acute to chronic infections, such as boils, deep tissue abscesses, enterocolitis, bacteriuria, osteomyelitis, pneumonia, carditis, meningitis, septicemia and arthritis (Jensen and Lyon, 2009). Before the beginning of antibiotic era, treatment of severe $S$. aureus infection was difficult. However, introduction of the $\beta$-lactam antibiotic penicillin into clinical use dramatically improved the situation. But, within a few years, S. aureus began to show resistance to penicillin. later on although $\beta$-lactamase resistant penicillins (e.g. methicillin, oxacillin) were developed and found effective, S. aureus strians resistant to methicillin an oxacillin were also isolated with increasing frequency (Reygaert, 2013). Large mobile genetic elements appear to encode both antibiotic resistant factors and proteins that are responsible for increase in virulence thus giving the organism the ability to adapt to the selective pressure of antibiotics (Ojo et al., 2014).

Abuse of antibiotics is a common phenomenon in developing counties including Bangladesh. Due to the widespread use of antibiotics, Staphylococcus aureus has rapidly developed resistance to many antibiotics making treatment difficult. So, the study was further extended to determine the antibiotic resistance profile of $S$. aureus isolates. For this purpose, all the $16 \mathrm{~S}$. aureus isolates were tested against 14 antibiotics (Table 5). Among the isolates, $87.5 \%$ exhibited resistance to ceftazidime; $50 \%$ to penicillin $\mathrm{G} ; 31.25$ $\%$ to cefotaxime; $25 \%$ to ceftriaxone, cefuroxime, cloxacillin; and $18.75 \%$ to amoxicillin (Fig 2). Agbagwa and Jirigwa (2015) also reported high level (100\%) of resistance by $S$. aureus isolates to ceftazidime. In the present study, all of the $S$. aureus isolates $(100 \%)$ showed susceptibility to amikacin, ciprofloxacin, erythromycin, gentamicin, imipenem, nitrofurantoin and vancomycin. One hundred percent susceptibility of $S$. aureus isolates to vancomycin was also reported by Akpaka et al. (2006). Our result is also in agreement 
with previous studies where erythromycin and gentamicin were found highly effective against S. aureus (Agbagwa and Jirigwa; 2015, Akpaka et al. 2006; Ako-Nai et al., 2005).

Table 5. Zone of inhibition produced by the antibiotic against $S$. aureus isolates

\begin{tabular}{c|cccc|c|c|c|c|c|c|c|c|c|c|c}
\hline Isolates & \multicolumn{10}{c}{ Zone of inhibition $(\mathrm{mm})$} \\
& AML* & AK & CTX & CAZ & CRO & CXM & CIP & OB & E & CN & IPM & F & P & VA \\
\hline SA1 & 23 & 31 & 24 & 18 & 24 & 33 & 31 & 9 & 30 & 35 & 43 & 28 & 27 & 19 \\
SA2 & 21 & 27 & 17 & 14 & 18 & 25 & 27 & 20 & 24 & 29 & 38 & 23 & 24 & 16 \\
SA3 & 9 & 29 & 10 & 8 & 9 & 7 & 29 & 0 & 29 & 26 & 34 & 20 & 8 & 16 \\
SA4 & 20 & 28 & 21 & 13 & 21 & 25 & 18 & 19 & 25 & 28 & 40 & 23 & 25 & 17 \\
SA5 & 21 & 25 & 22 & 14 & 22 & 30 & 26 & 15 & 24 & 27 & 41 & 25 & 23 & 20 \\
SA6 & 28 & 28 & 21 & 15 & 21 & 18 & 26 & 21 & 30 & 25 & 36 & 19 & 24 & 16 \\
SA7 & 26 & 27 & 21 & 14 & 17 & 23 & 25 & 19 & 25 & 24 & 32 & 21 & 32 & 16 \\
SA8 & 8 & 26 & 11 & 9 & 12 & 9 & 21 & 7 & 26 & 21 & 32 & 18 & 8 & 16 \\
SA9 & 30 & 32 & 7 & 8 & 16 & 16 & 25 & 21 & 26 & 34 & 45 & 21 & 33 & 20 \\
SA10 & 32 & 35 & 19 & 9 & 17 & 15 & 35 & 26 & 24 & 35 & 46 & 21 & 35 & 21 \\
SA11 & 19 & 28 & 9 & 7 & 13 & 10 & 30 & 21 & 21 & 33 & 40 & 22 & 27 & 20 \\
SA12 & 31 & 35 & 12 & 7 & 14 & 9 & 34 & 0 & 29 & 30 & 44 & 22 & 38 & 19 \\
SA13 & 22 & 24 & 17 & 13 & 16 & 21 & 24 & 18 & 26 & 24 & 34 & 21 & 30 & 16 \\
SA14 & 26 & 28 & 18 & 13 & 13 & 21 & 24 & 17 & 24 & 28 & 33 & 25 & 34 & 17 \\
SA15 & 26 & 30 & 19 & 9 & 21 & 25 & 27 & 21 & 23 & 30 & 40 & 21 & 22 & 16 \\
SA16 & 25 & 27 & 19 & 12 & 16 & 23 & 26 & 20 & 26 & 27 & 35 & 22 & 31 & 16 \\
\hline
\end{tabular}

*AML: amoxicillin; AK: amikacin; CTX: cefotaxime; CAZ: ceftazidime; CRO: ceftriaxone; CXM: cefuroxime; CIP: ciprofloxacin; OB: cloxacillin; E: erythromycin; CN: gentamicin; IPM: imipenem; F: nitrofurantoin; P: penicillin G; and VA: vancomycin.

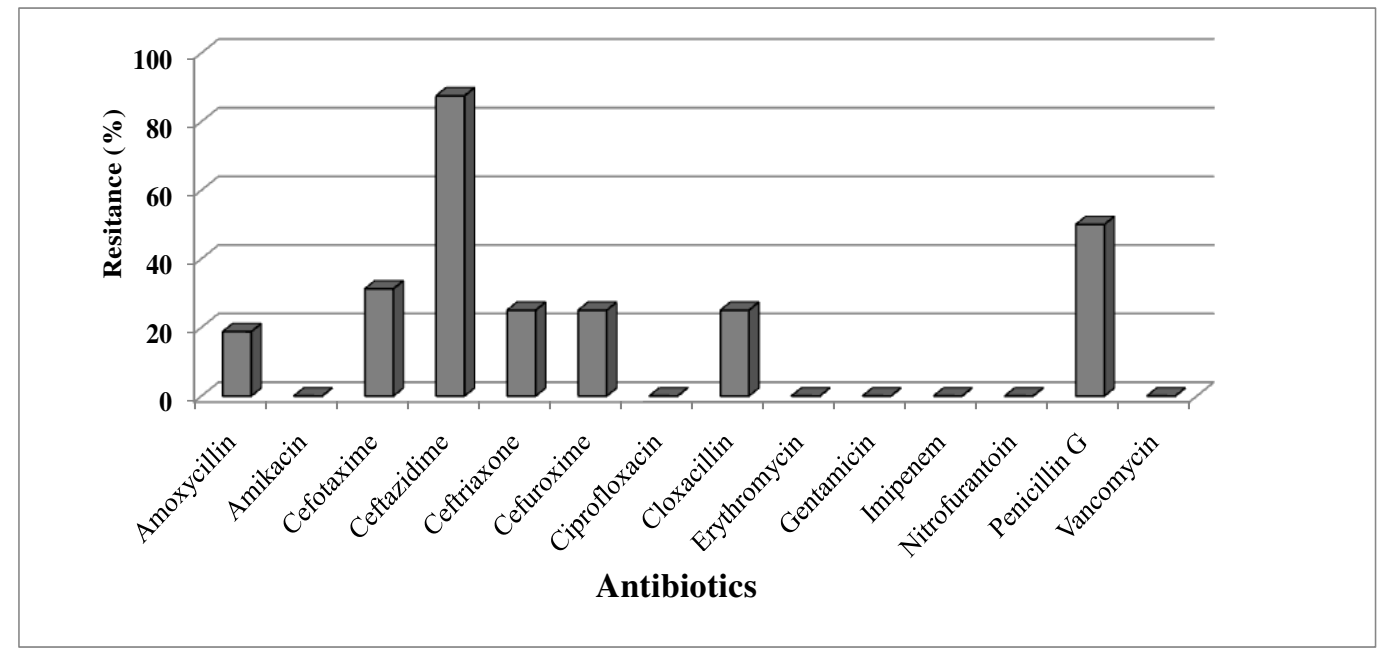

Fig. 2. Antibiotic resistance profile of the $S$. aureus isolates

The present study revealed that the indoor and outdoor air of the different sampling sites of JU campus was highly contaminated with bacteria and fungi during the study period. Furthermore, the presence of antibiotic-resistant bacteria in air has aggravated the contamination problem. 
Acknowledgement: The authors would like to thank Jahangirnagar University authority for financial support.

\section{REFERENCES}

Agbagwa, O.E. and Jirigwa, C.E. 2015. Antibiotics resistance and plasmid profile of Staphylococcus aureus from wound swabs in port Harcourt Nigeria. Curr. Res. Bacteriol. 8 (3): 70-76.

Ako-Nai, A.K., Adeyemi, F.M., Aboderin, O.A. and Kassim, O.O. 2005. Antibiotic resistance profile of staphylococci from clinical sources recovered from infants. African J. Biotech. 4 (8): 816-822.

Akpaka, P.E., Kissoon, S., Swanston, W. and Monteil, M. 2006. Prevalence and antimicrobial susceptibility pattern of methicillin resistant Staphylococcus aureus isolates from Trinidad \& Tobago. Ann. Clin. Microbiol. Antimicrob. 5:16.

Azimi, F., Naddafi, K., Nabizadeh, R., Hassanvand, M. S., Alimohammadi, M., Afhami, S. and Musavi, S. N. 2013. Fungal air quality in hospital rooms: a case study in Tehran, Iran. $J$. Environ. Health Sci. Eng. 11:30.

Bauer, A.W., Kirby, W.M. M., Sherris, J.C. and Turck, M. 1966. Antibiotic susceptibility testing by a standardized single disk method. Amer. J. Clin. Pathol. 45 (4): 493-496.

Bonetta, S., Bonetta, S., Mosso, S., Sampo, S. and Carraro, E. 2010. Assessment of microbiological indoor air quality in an Italian office building equipped with an HVAC system. Environ. Monit. Assess. 161:473-483.

Brandl, H., Fricker-Feer, C., Ziegler, D. Mandal, J., Stephan, R. and Lehner, A. 2014. Distribution and identification of culturable airborne microorganisms in a Swiss milk processing facility. J. Dairy Sci. 97 :240-246.

Brochu, P., Ducre-Robitaille, J. and Brodeur, J. 2006. Physiological daily inhalation rates for freeliving individuals aged 1 month to 96 years, using data from doubly labeled water measurements: a proposal for air quality criteria, standard calculations and health risk assessment. Human Ecol. Risk Assess. 12 (4):675-701.

Brooks, G.F., Caroll, K.C., Butel, J.S. and Morse, S.A. 2007. Jawetz, Melnick and Adelberg's Medical Microbiology. 24 ed. The McGraw-Hill Co. New York, pp: 224-230.

Cappuccino, J. G. and Sherman, N. 1996. Microbiology: A laboratory Manual, 4th ed. The Microbiology: A laboratory Manual, 4th ed. The Benjamin Cummings Publishing Co Inc. USA.

CEC (Commission of the European Communities). 1993. Indoor air quality and its impact on man. Biological particles in indoor environments. European Communities Commission. Report 12.

Clinical and Laboratory Standards Institute (CLSI). 2006. Performance standards for antimicrobial disk susceptibility tests; approved standard. ninth edition. CLSI document M2-A9, 26(1): 1-37.

Eduard, W., Heederik, D., Duchaine, C. and Green, B.J. 2012. Bioaerosol exposure assessment in the workplace: The past, present and recent advances. J. Environ. Monit. 14: 334-339.

Ekhaise, F. O. and Ogboghodo, B.I. 2011. Microbiological indoor and outdoor air quality of two major hospitals in Benin city, Nigeria. Sierra Leone J. Biomed. Res. 3(3) :169-174.

Hayleeyesus, S.F. and Manaye, A.M. 2014. Microbiological quality of indoor air in university libraries. Asian Pac. J. Trop. Biomed. 4(S1): S312-S317.

Holt, J.G., Krieg, N.R., Sneath, P.H.A., Staley J.T. and Williams, S.T. 1994. Bergey's manual of determinative bacteriology. 9 th edition. Williams \& Wilkins, Baltimore, Maryland. 
Jensen, S. O. and. Lyon, B. R. 2009. Genetics of antimicrobial resistance in Staphylococcus aureus. Future Microbiol. 4(5): 565-582.

Meadow, J.F., Altrichter, A.E., Kembel, S.W., Kline, J., Mhuireach, G., Moriyama M. Northcutt, D., O'Connor, T.K., Womack, A.M., Brown, G.Z., Green, J.L. and Bohannan, B.J. 2014. Indoor airborne bacterial communities are influenced by ventilation, occupancy, and outdoor air source. Indoor Air. 24(1): 41-48.

Ojo, S.K.S., Sargin,, B.O. and Esumeh, F.I. 2014. Plasmid curing analysis of antibiotic resistance in $\beta$-lactamase producing Staphylococci from wounds and burns patients. Pak. J. Biol. Sci. 17: 130-133.

Reygaert, W.C. 2013. Antimicrobial resistance mechanisms of Staphylococcus aureus. In: Méndez-Vilas, A. (ed.) Microbial pathogens and strategies for combating them: science, technology and education. pp. 297-305. Formatex Research Center, Badajoz, Spain.

Schulz, J., Hartung, J., Seedorf, J. and Formosa, L. C. 2004. Staphylococci as an indicator for bacterial emissions from a broiler house. Int. Soc. Ani. Hyg. Sant-Maolo. 75-78

Stryjakowska-Sekulska, M., Piotraszewska-Pająk, A., Szyszka, A., Nowicki, M. and Filipiak, M. 2007. Microbiological quality of indoor air in university rooms. Polish J. Environ. Stud. 16 (4): 623-632. 